\title{
A Pragmatic Analysis of Humor Words in English Advertisements
}

\author{
Xiaqing $\mathrm{Li}^{1}$ \\ ${ }^{1}$ Department of Foreign Language School, Shanxi Normal University, Linfen, Shanxi, China \\ Correspondence: Xiaqing Li, Department of Foreign Language School, Shanxi Normal University, Linfen, \\ Shanxi Province, China. E-mail: 1658926351@qq.com
}

Received: March 29, 2016 Accepted: May 5, 2016 Online Published: June 1, 2016

doi:10.5539/ells.v6n2p193 URL: http://dx.doi.org/10.5539/ells.v6n2p193

\begin{abstract}
As an independent discipline, pragmatics was through out thirty years' development. It is also a young discipline. As a medium emerging commonly in advertising language art, humor has attracted wide attention of many producers. Previous scholars analyzed more from the perspective of grammar, vocabulary, rhetoric, etc. But the research of advertising language humor is lacking from the aspects of pragmatic rules. Our collection of data is quite open. Any advertisement that can be transcribed in to written form is our interest. They are excerpted from magazines, advertisement, collecting books, newspapers, TV and radio commercials. As we only focus on language humor, situational humor produced by visual performance is not involved this thesis. The advertising language art of humor has been widely paid attention. Based on the existing theories of humor research, author of this paper used many kinds of pragmatic theories to analyze English advertising humor language, and including reference, deixis, anaphora, presupposition, speech act theory, the cooperative principle, conversational implicatures, and the politeness principle. It can not only provide reference for the research of this field for later scholars, but also provide theoretical guidance for the AD makers of using humor language to produce a good advertising effect.
\end{abstract}

Keywords: pragmatic theories, advertising, humor

\section{Introduction}

With the rapid development of market economy the advertising language has become an important subject of pragmatic study because of the lively and powerful influence, humorous pragmatic way widely used in advertising. Advertising is a kind of promotion, but it is also a kind of special communication process. Both sides respectively are advertising audience and advertising audience. Experienced advertising makers produce successful humorous discourse in different ways or methods. Humor application contains a lot of advertising strategies. A producer should take in-depth insight into the audience's psychology so as to apply humor effectively into productions and strategies of advertising. Seal developed the Austin's speech act theory, and he believed that language is a communicative process consisting of one another speech acts. Every speech act reflects the intention of the speaker. According to state of mind, adaptation range, and the purpose of speech ACTS, he made classification and generalization of speech acts. Who is in real need, talker in the implementation of a speech act would meet its intention to speaker in direct or indirect way. In advertising language, advertising marketing reflects humor with a direct or indirect way according to different psychological state of different objects and different occasions with different marketing purposes, so as to win the audience's heart and better to achieve marketing purposes. This thesis consists of five parts. The first part introduces the background of witting this thesis; the second part introduces the advertising humor language and pragmatics. The third part analyzes the advertising humor language from two aspects, and that are micro-pragmatics and macro-pragmatics. Among the analysis the author uses the reference, deixis, presupposition in the micro-pragmatics and the indirect speech act, the cooperative principle and its maxims, conversational implicatures, the politeness principle, and the principle of optimal relevance in macro-pragmatics. The last part is the conclusion.

\section{Theoretical Review}

\subsection{Introduction to the Pragmatic Theories}

Pragmatics, as the study of language in use is a young science. G. Leech (1983) remarks that "fifteen years ago, pragmatics was mentioned by linguists rarely, if at all". And if indeed pragmatics was mentioned at all, it was 
more in the guise of "ragbag" or, as someone once put it, a "waste-paper basket" designed to take care of the overflow from semantics, in the same way that semantics itself once had been assigned the task of explaining whatever syntactic theories had been proved unable to deal with. Prejudice against pragmatics has not prevented it from developing. Since the early 1970s, a growing interest in pragmatics and pragmatic problems has been witnessed worldwide. The international journal of pragmatics came into being in 1977, and the International Pragmatics Association (IPrA) has been in existence since 1985. All this has shown that a pragmatic turn in linguistics has started (Liu, 2006, p. 142). In many ways, pragmatics is the study of speaker's intended meaning, or even the "invisible meaning, that is, how hearers recognize what is meant even when it is not actually said or written. Take a newspaper advertisement for example; think not only about what the words might mean, but also about what the adviser intended them to mean: BABY \& TODDLER SALE (Yule, 1985, p. 129). Pragmatic theories include reference, deixis, Anaphora, presupposition, speech act theory, indirect speech act theory, the cooperative principle and its maxim, conversational implicatures, the politeness principle and so on. In the following author will analyze English advertising humor with above theories.

\subsection{Introduction to the Humor in English Advertisement}

In today's era of consumption, advertising is filled with every corner of our lives. Advertising humor is more and more becoming a force for active, and it can not only make the boring product information vivid and interesting but also make advertising entertaining, and attract attention of the audience. Through causing the audience to stop, the advertisement can leave deep impression on the audience. Make it attracted by enterprises or service so as to make consumers to become loyal buyers. Advertising humor in its unique way is accepted by the audience, and is currently one of the most effective ways of spreading. Advertising humor mainly belongs to the category of the emotional appeal advertising, and it refers to the use to make people laugh and humor art gimmick to performance by causing audience to joy through aesthetic reflection to achieve the purpose of effective persuasion form of advertising. Like a cloud in the form of a comic book with printed ads, it has a funny plot or funny image of film and television advertising, while these all belong to the category of advertising humor. In other forms of perceptual appeal advertising and pure lyricism advertising, even by causing people's negative affection to stimulate or alarming, it achieves the persuasion of advertising. Since the beginning of the AD, after long-term developments and changes until this day, colorful appearance in front of consumers which can create a lot of goods sales are still important judgment standard of successful advertising. How to make advertising graphic creative and attract the attention of consumers is my heart to impress consumers so as to let them produce certain memories of advertising information. The AD itself is one of the key issues to resolve. Modern advertising has been absorbing all arts. Advertising designers use a variety of ways to make advertising graphic creative work to have the visual impact. Advertising humor graphically creates attitudes within external harmonic situation so as to make consumers fully relaxed, vigilant, and exclusion of advertising instinct. In the euphoric mood consumers experience a profound impression, and promote the formation of advertising and good attitudes of brand. Advertising graphics is used for spreading the information about goods or service to achieve good communication effect, and also must be abide by the principles. Modern advertisements should be humor in life to capture the public's aesthetic psychology and social psychology. Through using the skillful and impressive forms, it will show humor in advertisements. The audience through humorous scene images more accurately experience advertisement to convey emotion and purpose. This is the charm of humor advertising creative works. Verbal humor is often seen as a funny mechanism, and it can increase interest for the life. Therefore the analysis of advertising humor language provides a good guidance for advertising designers to design a carefully planned advertisement and add the finishing point for advertising language communication behavior of this special pen reference, so as to achieve the goal of advertising communication. At the same time it can cause more colleagues to learn from real advertisement which contains the excellent humor factors, so as to promote the upgrade of the development of advertising humor and further promote the spread of advertising effectiveness.

\section{Analysis of English Humor in the Advertisement in Micro-pragmatics}

\subsection{Reference}

In semantics, it is often assumed that the words we use to identify things are in some direct relationship to those things. The process here is called inference (Liu, 2006, p. 143).

A French glass company's advertisement: "the eyes are the window of your soul, in order to protect your Windows, please mount glass for your soul!"

In this advertisement the window refers eyes, and glass refers eye glasses, which impresses people on lively and vivid image. Although the company's advertisement is about glasses, it does not directly use the words like 
glasses; there is no direct description of good qualities of glasses which can bring good effects to your glasses. In order to make consumers to focus on the glasses, we know that many glasses company advertisements regard glasses as the center, but ignore the premise of wearing a pair of glasses. We can see many such words in a lot of advertisements such as "the glasses have magical effects, if you take the glasses, your eyes will achieve what effect". In the advertisement there is a premise that wearing a pair of glasses is important for your eyes, and as we all know that eyes are so important to a person's soul. So we will open the Windows of the soul that is wearing glasses. In terms of glass lenses, which give a person the feeling of finding everything new and fresh, which meet the need of attracting prompt consumers for advertising and stop to see the interesting advertisement and make the purpose of looking comfortable, and further make a person not easily get tired of feeling. In this way advertisement can not only achieve a effect of tactful persuasion, and but also send out an attractive glamour which shows the application of the specific functions of advertisements.

America is putting on the dog.

It's a comfort to know its Hush Puppies quality. When you are wearing Hush Puppies jeans and sweaters, you know you're in style with value that you can count on. At first glance the title America is putting on the dog, it gives one kind of incomprehensible absurd feeling and it is difficult to arouse the exhausted note of reader. But if then you make the deep reading carefully, you could know here dog actually refers to Hush puppies, because puppies puppy also has meaning. This advertising humorous effects show that advertising creators are evasive and experience alleged practices, and cleverly hidden their true intentions. The advertising headline is like riddles, if you want to find the answer, you need to find the reference. This game-like effect can give the reader the impression that it is difficult to to be easily erased.

\subsection{Deixis}

In all languages there are many words and expressions whose references depend entirely on the situational context of the utterance and can only be understood in light of these circumstances. This aspect of pragmatics is called deixis, which means "pointing via language. Any linguistic form used to do this "pointing" is called a deictic expression (Liu, 2006, p. 144). In order to achieve communicative purpose and intention instructions in a certain context must make them clear to readers in a certain context that referred to in it. The following hot sauce advertisement proves this point.

For real brain-scalding, colon-burning taste, try Joes Atomic Chill.Made from 100\% animal by products and just a dish of diesel fuel,Its a burst of flavor that will make your tongue turn black and drop to the floor quivering in fear.So for a true gastro-intestinal assault,try Joes...

In the advertisement advertising producers use extremely "heat" to indicate the effect of hot sauce; humorous description of the "hot" chili sauce is directly. Now the vivid advertising language makes a strong and direct visual impact to the audience eyes. Without any thinking, the audience has felt humor in stitches, left a deep impression. Chili sauce of advertising is like to eat chili for the audience, so advertisers directly exaggerate its "hot" style of humor, and use the technique instructions to involve the audience into the context of advertisement. There is joy to win the audience. At the same time it plays a promotion effect.

\subsection{Presupposition}

If some one tells you "your girlfriend is waiting outside for you", there is an obvious assumption that you have a girl fiend. If you are asked the following question, there are at least two assumptions involved: When did you stop beating your wife? Here, the speaker assumes that you used to beat your wife and that you no longer do so. Such assumptions by the speaker or writer are called presuppositions (Liu, 2006, p. 146). "Contains the default" is produced by the humor. "Default" is what the speaker talk when setting the listener to know information; it mainly refers to people who are attached to the surface structure of some of the side of setting information or something (Zhu, 1993).

\section{If your pay packet was one pound short each week, who would really notice?}

The surface meaning is: you are very rich, you less pay envelop a pound a week, don't notice. So who will really notice? To look down to readers will find unexpected answer: You'll motion notice the difference, but they will. (photo of impoverished farmers hoeing). This sentence also implicitly compliments you, but you won't notice, because the kindness is you become accustomed to quality. The default information in this advertisement should be based on the common knowledge and context, so the advertising designers can accurately predict the listener in the mood. How much of the landscape in context communication information can automatically fill up is "contains the default". The crucial factor "contains the default" in advertising is often the rhetorical question as in this advertisement. It implies humorous, profound implication, and rich semantics, which can express the 
speaker's presupposition of strong language. Western charitable advertising often have such meaning in complex asked words as this advertisement. What it sells is not products, but is a kind of good image.

\section{Analysis of the Advertising English Humor in Macro-pragmatics}

\subsection{Indirect Speech Act theory}

A different approach to distinguishing types of speech acts can be made on the basis of structure. It is an utterance whose literal meaning and intended meaning are different (Liu, 2006, p. 151).

You're better off under the Umbrella.

This is a travel insurance company's advertising. In the advertisement we can't know clearly information which the word umbrella referred to.The advertising designers use umbrella to create the metaphors about umbrella, and leave an image to make the visitors to feel that to buy insurance, that is to go out Safe and sound, is like place where a person place oneself under a umbrella (umbrella is here Invisible); And "better off" refers to "more comfortable, more happiness". In this advertisement it is difficult for us to understand intended meaning in according to its literal meaning. What we can predict from literal meaning is that if you bought this insurance you would have felt more comfortable and safer. But indirect speech act is that buying this insurance will make your travel more comfortable, and more fun.

\subsection{The Cooperative Principle and Its Maxims}

Grice proposed the concept of implicatures in his famous work logic and conversation. He believed that in order to make to make the conversation to progress well speakers and hearers both abide by a principle that is the cooperative principle. There are four principles in Grice's cooperative principle: (1) maxim of quantity; that is what is said should include the necessary information in the aims of present conversation. (2) maxim of quality; you can't say words that you think it false, and you can say the words no enough evidence in this principle. (3) maxim of relation; the conversation should be of relation, that is the words you say should be on the point. (4) maxim of manner; the words can be clearly understood, simple, and in order well. But they can't be difficult to understand and ambiguity. Through the cooperative principle utterances spoken by speakers who are in involved in conversation will be related with each other and cooperate with each other so as to achieve the goal of successful communication. In the real process of communication there are a large number of situations of violating these principles. In the advertising language people often intentionally violate these principles so as to produce implicatures. Humor originates in speculation and reasoning of utterances. (Liu, 2006, p. 154)

\subsubsection{Humor in Violation of Maxim of Quality}

\section{Sainbury's Fromage Frais. One taste and you're doomed... It'll just make you feel like more.}

In a word, it's irresistible. This short advertisement is elected from a food advertisement. "Sainbury's Fromage Frais" is a Soft low-fat cheese. Advertising authors use derogatory phrase to be doomed to Almost sub-context to tell the reader that eating this cheese is out of luck, which is not only in violation of the maxim of quality but also seems out of context. But here the recipient of words beyond the surface significance of discourse from the perspective of meeting the criteria to understand the meaning of this sentence and make pragmatic reasoning, which creates overtones: This kind of cheese is delicious, once one eat it, he or she would be addicted to it in "bad luck" and and can't help putting it down. Through praise of the derogatory term the designers use irony means to strengthen the effect of performance and attraction of the language. Humorous and witty meanings are fleshed out.

\subsubsection{Humor in Violation of Maxim of Quantity}

There is an advertisement published in advertising column of a newspaper in Britain:

"This Dentists GP Urgent need for a female secretary and receptionist, please hang up the phone to contact,

if there is no electrical connection, then the position is still vacant."

This advertisement really should be the most common one: There are those who want to engage, please contact us. But advertising authors intentionally gild a lily to provide excess information violate the maxim of quantity to produce overtones and a special purpose. By means of humor the designer adds fun to the most common advertisement to achieve the objective purposes of attracting attention of audience.

\section{"Do not peek."}

This is an advertisement in front of a bar in Bangkok, Thailand. It is written in the top of a giant barrel. Passers-by do not know exactly the meaning, and nobody is not be curious about it so as to head out to see what happened, following one wine fine taste is in sight of nostrils. There is another word written in the barrel "Our 
wine is unique, and we invite you to enjoy." Shopkeeper initially do not provide sufficient amount of information deliberately, while generate conversational meanings through violations of the maxim of quantity, that is, there must have a mystery and some surprising things in the bucket. By the means of mystifying and degradation after the first praise, The shopkeeper takes advantage of people's curiosity, and leads customers to guess at the same time and then makes up with information: "our wine is unique, and we invite you to enjoy" so as to achieve advertising purposes.

\subsubsection{Humor in Violation of Maxim of Relation}

"We refuse to believe in the equality of the sexes."

This is the headline of Mercedes-Benz gasoline Car advertisement. We do not believe that men and women are equal. But why the car has sex, do not? This sentence seems not very in conformity with this context of car. In times of equality between men and women this sentence is not very conform to the trend. The designers deliberately violate the maxim of relation to try to make the illusions of concept of car and people, cause the difficulties of decoding and then let people temporarily not know meaning in it. In fact, what Mercedes-Benz cars propaganda are their colorful car styles. There are styles that men like, and the designs that women love. When people speculate, explore, and investigate its meaning within the session, humor is produced. So we can see that visible and fuzzy meanings in violation of maxim of relation can also create humor.

\subsubsection{Humor in Violation of Maxim of Manner}

A travel agency in Netherlands published an advertisement: "Please go to Arctic to spend honeymoon now"! Local night is 24 hours long

This advertisement is clearly appealing to newlyweds who want to travel to some places to spend honeymoon. Honeymoon in advertisement can not give such impression on audience that how good honeymoon in the North Pole. There is no direct positive effect on audience, but politely tell the newlyweds that night is 24 hours long. Obscure and vague discourse in violation of the maxim of manner result in the implication: long nights in the Arctic just for the newly married who are gluey and devoted, there is no better place to spend a honeymoon for the newlyweds. This advertisement grasps the audience's heart because of its obscure, subtle and raw humor.

\subsection{Conversational Implicatures}

Grice's basic idea is that in communication, speakers aim to follow the CP and its maxims, and that hearers interpret utterances with these maxims in mind (Liu, 2006, p. 154). Combining the understanding process of advertising humor with conversational implicature and cooperative principle, viewers are able to see the humor in advertisement, because they understand the the meaning of advertising containing. Paul Grice proposed a "Cooperative Principle" in how to use the language on the basis of the development of the theory of conversational implicature, which talks about that the follow or breach of principles of the four different levels will produce conversational implicature and the humor is reflected. The meaning of the effect of the conversational Implicature follow is called "Standard Implicature", (Standard) Razor advertisement such as the following:

Only Norelco shave below the skin while floating over your face.

This advertisement means that only the Norelco lightly across over the surface of the face under the skin, the beard can be handed off. Viewers do not need to be told what "Norelco" is. According to a few words of advertising such as "shave", "skin" and other words and its relevance, it's not hard for the audience to guess that it is a razor.

Please look at the following advertisement, which is the dialogue form:

"not brand new, Bran News, It's a cereal."

"What's its name?"

"That is its name."

"What's its name?"

"Bran News! It's a bran cereal that stays extra crunchy in milk. And it's honey roasted for great taste."

"So what's it called?"

"I know it's brand new, so what's its name!!"

"I just told you its name!"

"I see I'm getting no where with you." 
This is a cereal advertisement in Bran News. Through simulation scene the advertisement, by the form of dialogue, is very vivid. In the advertisement words are repeated several times to deepen the impression on the audience. Advertisements in form of virtual dialogue although have misunderstanding on both sides, the audience can find out the related information, it is not difficult for them to find its meaning, thus draw the correct name and get the misunderstanding of humor.

You are very rich; you less pay envelop a pound a week. Don't notice, so who will really notice?

To look down to readers will find unexpected answer: You'll notice the difference, but they will (photo of impoverished farmers hoeing). This sentence also implicitly compliments you. You won't notice, because the kindness is you become accustomed to quality.

\subsection{The Politeness Principle}

The cooperative principle alone cannot fully explain how people talk. It explains how conversational implicature is given rise to but it dose not tell us why people do not say directly what they mean. Why, for instance, do people say "Could you give me a lift"? The reason has to do with another principle which applies to conversation in addition to the Cooperative Principle - the Politeness Principle (PP). (Liu Runqing, 2006, p. 157) Please see the advertisement below: automobile advertisement.

\section{We would never say the new Audi10015 the best in its class. We don't have to.}

A meaningful, witty humor advertisement is not surprising, and understandable. Follow the politeness principle, from the sentence of advertisement the reader can think that goods are not enough, but advertisement is self-evident. You think the advertisement is funny, also surprising. Cognitive psychology believes that humor is a kind of mechanism not harmonious too. That is to say, the expected result has often been rejected, and the actual result and listening words are often not same; this disharmony make two kinds of contradictory results, but follow the politeness principle and the formation of humor. At the same time, what humor also manages to make is not gradually to provide information of a corpus in a discourse, but all of a sudden it can extremely riches information especially in language of end of the discourse. Therefore, we can not imagine the results from discourse proposition, but the transition to completely different results can produce a kind of "amazing effect". The expected result that is not consistent with the actual result is a quiet song of the main features.

\subsection{The Principle of Optimal Relevance}

Sperber \& Wilsonde think that any straight dominant language communication activities are vigilant, and our activity has the best relational meaning with language. The speaker's words always follow the principle of optimal relevance, namely in the process of cognition the appropriate people get enough contextural effect. "No connection" in advertising humor is only a surface phenomenon. Even if the discourse relevance of the speaker is small, but the listener can pass the additional efforts through a larger effort. What communication is associated with derived from "no connection" on the surface of the optimal relevance, only on the basis of it the hearers can complete the understanding of discourse, and humorous effects.

If people keep telling you to quit smoking cigarettes, don't listen...... They're Probably trying to trick you into living for a long time.

According to reasoning process of relevance theory the direct advertising information is "if someone always suggests you not smoke, don't listen to them". The object in advertisement, of course, is the general smokers, and advertising audience naturally deduces the conclusion of the semantics that "I can keep smoking". However, Grice (2011) argues that people's normal communication should abide by "Cooperative principle". There are four prospects in its principle. Standards in the maxim of quality of its four prospects require that the speaker tell the truth. Combining this premise with the advertisement, the audience can see at a glance that the sentence in advertisement "don't listen", which means that smokers do not listen to the advice, is not the truth for violating the maxim of quality. The latter words "they are probably trying to trick you into living for a long time", such new information also overthrows the contextual assumptions and conclusions previously made, so the audience had to deductively reason again. The deductive conclusion and the first conclusion are on the contrary, namely, smoking endangers life, so no smoking. Advertising audience applies contextual assumption based on the optimal relevance in understanding process of discourse. When derived conclusions can not meet the expectation of optimal relevance, recipient will look for contextual assumptions of other correlations lower than the level of the previous relevance until the conclusion satisfies the expectation of correlation. Humorous utterances contain some inharmonious, unlogical, ridiculous, and unexpected elements, and the receiver must firstly understand these elements, that is, he must go to perceive the significance of disharmony factors, then to find implicit harmony in inharmonious elements so as to understand the real intention expressed by advertising producers 
through the humor. In the process of understanding some humorous language when the new information conflicts with the known contextual assumption, people are forced to make a semantic transition. They will abandon the original contextual assumptions and overturned explanations made previously, then look for a new and optimal relevance contextual assumption and finally make it composite with new information so as to make the new and reasonable explanation.

\section{Conclusion}

In conclusion, this thesis is based on the data analysis and logical reasoning, hence it is mainly qualitative. The qualitative analysis discussed the humorous advertising language from the perspective of pragmatic theories. Apart from the author's own observations, previous findings and significant literature will be unavoidably referred to. Our collection of data is quite open. Any advertisement that can be transcribed in to written form is our interest. They are excerpted from magazines, advertisement, collecting books, newspapers, TV and radio commercials. As we only focus on language humor, situational humor produced by visual performance is not involved this thesis. The advertising language art of humor has been widely paid attention. Previous researches mainly depend on the uses of language skills for the study of advertising language humor, or analyze only from several aspects such as a single speech act theory, conversational implicature theory. Few people made a more comprehensive study from the angle of pragmatics. Being under the perspective of pragmatics, this thesis selects some humor advertising language to analyze the advertising humor with many theories of pragmatics, and points out the significance of existence in advertising humor phenomenon, not only providing theoretical guidance for the advertising makers to produce a good advertising effect but also providing reference for later scholars and improving the cognition and understanding of humor slogan.

\section{References}

Bloom, P. (1994). Language Acquisition: Core readings. Cambridge: MIT Press.

Chang, G. P. J. (2008). Cognitive and pragmatic features of advertising language. Language and Literature Learning.

Forrester, M. (1996). Psychology of language: A Critical Introduction. London: Sage Publications. http://dx.doi.org/10.4135/9781446279229

Garman, M. (1991). Psycholinguistics. Cambridge: Cambridge University Press.

George, W. J. (1998). You Must Be Joking. Modern English Teacher, N(3).

Grice, D. (2011). Cooperative Principle. Retrived from http://blog.sina.com.cn/s/blog_4c00a2ac0100s48h.html

Gui, S. C. M. (2000). Psycholinguistics (new edition). Shanghai: Shanghai Foreign Language Education Press.

He, Z. X. M. (2000). A New Introduction to Pragmatics. Shanghai: Shanghai Foreign Language Education Press.

Hu, Z. L. M. (2001). Linguistics, A course book. Peking: Peking University Press.

Jiang, W. Q. M. (2000). PRAGMATICS Theories \& Applications. Beijing: Beijing University Press.

Jiang, W. Q. M. (2003). Contemporary Pragmatics. Beijing: Beijing University Press.

Joanna, C. M. (2000). Vagua Language. Shanghai: Shanghai Foreign Language Education Press.

Johnson, M. (1987). The Body in the Mind: The bodily Basis of Meaning. Chicago: University of Chicago Press.

Lan, C. M. (2005). The Study of Cognitive Linguistics and Metaphor. Beijing: Foreign Language Teaching and Research Press.

Liu, R. Q. M. (2006). Linguistics: A New Course Book. Beijing: Foreign Language Teaching and Research Press. Mao, R. G. M. (1993). English Humor Appreciation. Shanghai: Shanghai Academy of Social Sciences Press.

Sampson, G. C. (1980). Schools of Linguistics: Competetion and Evolution. London: Hutchinson.

Wang, W. B., \& Ling, B. J. (2003, July). English Verbal Humour: A Cognitive Pragmatic Inquiry. Journal of Foreign Languages General Serial, 146(41), 32-38.

Wang, X. Y. J. (2010). The constructing of cognitive linguistic context to the words meaning of advertising language with a double meaning. China Science and Technology Information.

Yang, Y. H., \& Tang, D. J. (2007). Research into the Pragmatic Failuresin Advertising Language and Its Countermeasures. Journal of Wei Fang Educational College.

Yang, Y. L. J. (2002). A Scio-cognitive Study of Chinese Students' Codability in English. Beijing: Tsinghua 
University Press.

Zhao, Y. F. J. (2001). An Introduction to Cognitive Linguistics. Shanghai: Shanghai Foreign Language Education Press.

\section{Appendix}

\section{Advertisements in This Paper and Its Origin}

(1) A French glass company's advertisement: "the eyes are the window of your soul, in order to protect your Windows, please mount glass for your soul!” (http://wenda.so.com/q/1369523720067448)

(2) America is putting on the dog (http://www.doc88.com/p-97439845302.html)

(3) For real brain-scalding, colon-burning taste, try Joes Atomic Chill.Made from 100\% animal by products and just a dish of diesel fuel, Its a burst of flavor that will make your tongue turn black and drop to the floor quivering in fear. So for a true gastro-intestinal assault, try Joes.

(http://www.doc88.com/p-0814329953828.html).

(4) If your pay packet was one pound short each week, who would really notice? (Christian Aid) (Myers, 1994) (http://wenku.baidu.com/view/b153763383c4bb4cf7ecd1fb.html)

(5) You are better off under the Umbrella. (http://www.wenkuxiazai.com/doc/8c98d0aadd3383c4bb4cd2fb.html)

(6) Sainbury's Fromage Frais. One taste and you're doomed... It'll just make you feel like more. (http://www.docin.com/p-586236682.html)

(7) "This Dentists GP Urgent need for a female secretary and receptionist, please hang up the phone to contact, if there is no electrical connection, then the position is still vacant." (http://wenku.baidu.com/view/57d4a4533c1ec5da50e270e1.html)

(8) “Do not peek." (https://www.so.com/s?ie=utf-8\&src=hao_search\&shb=1\&hsid=\&q=do+not+peek)

"We refuse to believe in the equality of the sexes." (http://www.xzbu.com/3/view-1493712.htm)

(9) “Please go to Arctic to spend honeymoon now"! Local night is 24 hours long (https://www.so.com/s?q=请去 南极度蜜月, 当地夜长是 24 小时 \&src $=\mathrm{srp} \& \mathrm{fr}=$ hao_search\&psid=bfd $7585 \mathrm{~d} 805778 \mathrm{e} 253 \mathrm{f} 8 \mathrm{~d} 7 \mathrm{dee} 3 \mathrm{dc} 1 \mathrm{fa} 2$ )

(10) Only Norelco shave below the skin while floating over your face. (http://www.docin.com/p-434614724.html)

(11) "not brand new, Bran News, It's a cereal."

"what's its name?"

"That is its name."

"What's its name?"

"Bran News! It's a bran cereal that stays extra crunchy in milk.And it's honey roasted

for great taste."

"So what's it called?"

"I know it's brand new, so what's its name!!"

"I just told you its name!"

"I see I'm getting no where with you."

(https://www.so.com/s?ie=utf-8\&src=hao_search\&shb=1\&hsid=027e32c97ba4e517\&q=美国的麦片广告)

(12) You are very rich, you less pay envelop a pound a week. Don't notice, So who will really notice? (http://wenwen.sogou.com/z/q166301260.htm)

(13) We would never say the new Audi 10015 the best in its class. We don't have to (http://www.doc88.com/p-737752381745.htm)

(14) If people keep telling you to quit smoking cigarettes, don't listen...... They're Probably trying to trick you into living for a long time. (http://www.docin.com/p-434614724.html) 


\section{Copyrights}

Copyright for this article is retained by the author(s), with first publication rights granted to the journal.

This is an open-access article distributed under the terms and conditions of the Creative Commons Attribution license (http://creativecommons.org/licenses/by/3.0/). 